\title{
A 30-day Old Infant with Meningitis Due To Salmonella enteritidis: A Case Report
}

\section{Salmonella enteritidis'e Bağlı Menenjit Geçiren 30 Günlük Bir Bebek: Olgu Sunumu}

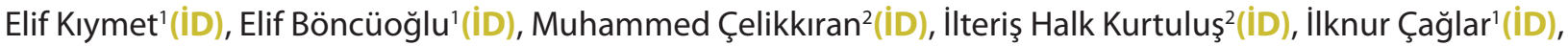 \\ Gamze Gülfidan³(ID), Nuri Bayram'(ID), İlker Devrim'(ID) \\ 'Clinic of Pediatric Infectious Diseases, Health Sciences University Dr. Behcet Uz Children's Diseases and Thoracic Surgery Training and Research Hospital, \\ Izmir, Turkey \\ ${ }^{2}$ Clinic of Pediatrics, Health Sciences University Dr. Behcet Uz Children's Diseases and Thoracic Surgery Training and Research Hospital, Izmir, Turkey \\ ${ }^{3}$ Clinic of Infectious Diseases and Clinical Microbiology, Health Sciences University Dr. Behcet Uz Children's Diseases and Thoracic Surgery Training and \\ Research Hospital, Izmir, Turkey
}

Cite this article as: Kıymet E, Böncüoğlu E, Çelikkıran M, Kurtuluş ï, Çağlar I, Gülfidan G, et al. A 30-day old infant with meningitis due to Salmonella enteritidis: a case report. J Pediatr Inf 2020;14(2):e76-e78.

\section{Abstract}

A 30-day-old male patient was presented to our clinic with a two-day history of fever and diarrhea. The patient was lethargic, and he had pulsatile bulged fontanelle in his physical examination. Cerebrospinal fluid examination was compatible with bacterial meningitis, and empirical antibiotic treatment was initiated. Salmonella enteritidis was detected in the cerebrospinal fluid culture. Cefotaxime was administered to the patient according to the results of the culture antibiogram, and the treatment was completed in 4 weeks. During follow-up, hydrocephalus developed, but surgical intervention was not required. The patient was discharged and followed-up as an outpatient. Salmonella meningitis is associated with severe clinical findings such as subdural effusion, hydrocephalus, cerebral infarction, subdural empyema, or brain abscess. Therefore, it has a high clinical importance. This case is presented to emphasize that meningitis due to $S$. enteritidis is rare, but these patients should be followed closely for possible complications.

Keywords: Infant, meningitis, hydrocephalus, Salmonella enteritidis
Öz

İki gündür devam eden ateş ve ishal şikayeti ile başvuran 30 günlük erkek hastanın fizik muayenesinde letarji, fontanelde pulsasyon ve bombelik saptandı. Yapılan lomber ponksiyon sonucunda elde edilen beyin omurilik sIVISI (BOS) incelemesi bakteriyel menenjit ile uyumlu bulundu ve ampirik tedavi başlandı. BOS kültüründe Salmonella enteritidis üremesi oldu. Hastanın tedavisine kültür antibiyograma uygun olarak intravenöz sefotaksim ile devam edildi ve tedavi dört haftaya tamamlandı. Hastanın izleminde hidrosefali gelişti ancak cerrahi müdahale gerekmedi. Hasta taburcu edilerek ayaktan izleme alındı. Salmonella menenjiti subdural efüzyon, hidrosefali, serebral enfarkt, subdural ampiyem veya beyin apsesi gibi ciddi klinik bulgularla ilişkilidir. Bu nedenle klinik olarak önem taşımaktadır. Bu olgu, S. enteritidis'e bağlı menenjitin nadir görülmesi ve bu hastaların gelişebilecek komplikasyonlar açısından yakın takip edilmesi gerektiğine dikkat çekmek amacıyla sunulmuştur.

Anahtar Kelimeler: Bebek, menenjit, hidrosefali, Salmonella enteritidis

\footnotetext{
Correspondence Address / Yazışma Adresi

Elif Kıymet

Sağlık Bilimleri Üniversitesi

Dr. Behçet Uz Çocuk Hastalıkları ve

Cerrahisi Eğitim ve Araştırma Hastanesi,

Çocuk Enfeksiyon Hastalıkları Kliniği,

İzmir-Türkiye

E-mail: elifkiymet_1264@hotmail.com
} 


\section{Introduction}

Salmonella spp. is a gram-negative bacillus of the Enterobacteriaceae family. With a wide clinical spectrum from asymptomatic gastrointestinal system carriage to bacteremia, non-typhoidal Salmonella (NTS) infection most frequently presents with a gastroenteritis clinic. Serious focal infections of the childhood with high mortality and morbidity, such as meningitis, brain abscess or osteomyelitis, are seen in $10 \%$ of the patients developing bacteremia (1).

Salmonella meningitis, though rare in developed countries, is the gram-negative pathogen causing bacterial meningitis in developing countries. It is associated with serious clinical findings including increased recurrence rates, subdural effusion, hydrocephaly, cerebral infarct, subdural empyema or brain abscess (2).

\section{Case Report}

A 30-day old male patient was presented to our hospital with fever ongoing for two days and diarrhea. History revealed that the patient had received amikacin and sulbactam-ampicillin treatment for 10 days in an epicenter for high fever when he was five-days old postnatally. Physical examination showed weight $3480 \mathrm{~g} \mathrm{(10-25} \mathrm{p),} \mathrm{height} 51 \mathrm{~cm}(25-50 \mathrm{p})$, head circumference $34 \mathrm{~cm}(3-10 \mathrm{p})$, body temperature $38.4^{\circ} \mathrm{C}$, increased inclination to sleep, faded color, weakened sucking and rooting reflexes, and anterior fontanelle opening at $3 \times 2 \mathrm{~cm}$, which was swollen and pulsatile. Other system findings were normal. Laboratory results were as follows: hemoglobin $11.7 \mathrm{~g} / \mathrm{dL}$, leucocyte count: $21.010 / \mathrm{mm}^{3}$, neutrophil rate: $80 \%$, thrombocyte count: $530.000 / \mathrm{mm}^{3}$, C-reactive protein: $12.8 \mathrm{mg} / \mathrm{dL}$ (with turbidimetry method, normal value $<0.5 \mathrm{mg} / \mathrm{dL}$ ). Leucocytes and erythrocytes were not observed in direct stool examination. Complete urinalysis, renal function tests, coagulation tests and liver transaminases were within normal limits. Blood, urine, and stool cultures were taken. Transfontanelle and abdominal ultrasonography (USG) and cranial computed tomography (CT) examinations were found normal.

In the cerebrospinal fluid (CSF) examination performed due to considering a central nervous system infection as preliminary diagnosis as a result of physical examination and clinical findings, elevated leucocytes were seen and CSF protein value and CSF glucose value were found respectively as $395.2 \mathrm{mg} / \mathrm{dL}$ (normal values: $20-80 \mathrm{mg} / \mathrm{dL}$ ) and $<5 \mathrm{mg} / \mathrm{dL}$ (normal values: $60-80 \mathrm{mg} / \mathrm{dL}$ ). Bacteria were not observed in Gram staining.

A broad-spectrum antibiotic was chosen for empirical treatment since the patient was septic upon referral to hospital and history revealed that the patient had previously received parenteral antibiotic treatment as an inpatient. The patient considered to have acute bacterial meningitis was started on intravenous vancomycin $60 \mathrm{mg} / \mathrm{kg} /$ day, intravenous meropenem 120 $\mathrm{mg} / \mathrm{kg} /$ day, and intravenous ampicillin $300 \mathrm{mg} / \mathrm{kg} /$ day after having taken blood and CSF cultures. CSF and blood cultures were closely followed.
Salmonella enteritidis grew in CSF and blood cultures on the third day of treatment and was seen to be susceptible to third and fourth generation cephalosporins and carbapenems. Vancomycin, meropenem and ampicillin treatments of the patient was terminated considering the culture antibiogram of the patient, and intravenous cefotaxime $300 \mathrm{mg} / \mathrm{kg} /$ day was started. No growth was seen in the stool and urine cultures of the patient, which were taken on admission to hospital.

In the evaluation performed for possible underlying immunodeficiencies due to $S$. enteritidis growth, immunoglobulin levels, lymphocyte panel and oxidative burst tests were determined normal.

Upon detecting the right lateral ventricle, left lateral ventricle and third ventricle larger than normal in the transfontanelle USG done at the third week of treatment, cranial magnetic resonance imaging (MRI) was carried out with the suspicion of hydrocephaly. Cranial MRI revealed enlargement in both ventricles and the third ventricle and significant findings suggestive of aqueduct stenosis. Since hydrocephaly was not present in the transfontanelle USG and cranial CT of the patient performed on admission, hydrocephaly findings seen on the MRI taken at the third week of treatment were considered to be a complication associated with $S$. enteritidis meningitis. The patient was consulted with neurosurgery, and surgical intervention was not deemed necessary. Patient's intravenous cefotaxime treatment was completed in four weeks. The patient was discharge, and regular head circumference measurements were made for hydrocephaly during outpatient follow-ups.

\section{Discussion}

The first salmonella meningitis case was reported by Ghon in 1907 (3). Salmonella strains are responsible for $5-13 \%$ of the acute bacterial meningitis in developing countries $(4,5)$.

This rate is $\leq 1 \%$ in developed countries; however, it still maintains importance by leading to a severe meningitis picture in children particularly under the age of two $(4,5)$. Previous studies have reported morbidity due to various complications at a rate of $50-90 \%$ and mortality rates as high as $50-70 \%$ in salmonella meningitis $(2,4,6)$.

Immunosuppression due to congenital or acquired reasons constitutes a risk for salmonellosis (7-9). In children with congenital immunodeficiencies especially like humoral immunodeficiency and chronic granulomatous disease, invasive NTS infection risk is elevated (10). Our patient was evaluated for immunodeficiencies but none was detected.

As in our patient, invasive NTS infection is most frequently encountered in infants (1). NTS-associated meningitis is high especially in infants younger than six months. Opsonization deficiency, low complement levels, insufficient phagocytosis and chemotaxis result in susceptibility in infants towards gram negative bacterial infections $(11,12)$. In a study evaluating patients 
with invasive NTS infection in Mali between 2002 and 2014, $80.5 \%$ of the cases were under 5 years and $25.3 \%$ of the cases were under 12 months of age (13). Neonates carry more risks for salmonella meningitis than the other age groups (5).

Since it is an intracellular organism, the treatment of Salmonella spp. is long, and there is a risk of recurrence following insufficient treatment $(12,14)$. Third generation intravenous cephalosporins for at least four weeks are recommended as first option in treatment $(1,14)$. Although using third generation cephalosporins has significantly reduced mortality and recurrence rates, salmonella meningitis still has the highest recurrence rate in all meningitis caused by bacterial organisms (15). Therefore, patients must be followed after being discharged. Though not having detected the agent in the neonatal period, our patient also received parenteral antibiotic treatment for ten days at an epicenter and then referred to our hospital and was diagnosed with meningitis that developed due to Salmonella spp.

Neurologic complications associated with salmonella meningitis, including ventriculitis, subdural empyema, hydrocephaly, and cerebral abscess have been reported in the literature $(2,4,6)$. Accordingly, between the years 1997 and 2006, subdural effusion was detected in $6.6 \%$ and hydrocephaly in $4.8 \%$ of the patients developing NTS-associated meningitis between the ages of 2 months and 16 years. While sequela development rate was found as $93 \%$ in the patient group developing complications like brain abscess, subdural effusion and hydrocephaly, this rate was found as $69 \%$ in the group not developing complications; however, the difference between was not statistically significant (4). Another study from Taiwan has reported in patients followed until school age after the development of salmonella meningitis that $52 \%$ suffered from language disorders, $48 \%$ from motor deficits, $5 \%$ from abducens nerve palsy, $5 \%$ from microcephaly, and $5 \%$ from hydrocephaly, and mortality in the acute period has been reported as $13 \%$ (6). Hydrocephaly was radiologically developed in our patient; however, progression was not seen during follow-up and a neurologic deficit was not confirmed in physical examination.

It is known that $S$. enteritidis, just as in our patient, is a more frequent cause of meningitis compared the other Salmonella types. A study has reported S. enteritidis-associated mortality rate of $27.8 \%(13)$.

To conclude, salmonella meningitis is a disease with high mortality and morbidity. Risk for this infection is elevated in immunosuppressed patients and infants. Patients receiving salmonella meningitis must be closely followed for acute complications such as abscess, empyema, and hydrocephaly and be monitored for neurological sequels that can develop in the long term.
Informed Consent: Patient consent was obtained.

Peer-review: Externally peer-reviewed.

Author Contributions: Concept - ID; Design - ID, NB, EK; Supervision - ID, NB; Resources - EK, EB, IÇ, MÇ, IHK; Data Collection and/or Processing - EK, EB, IÇ, GG; Analysis and/or Interpretation - ID, NB, EK; Literature Review - EK, EB, IÇ, MÇ, IHK; Writing - EK, ID; Critical Review - ID, NB.

Conflict of Interest: No conflict of interest was declared by the authors. Financial Disclosure: The authors declared that this study has received no financial support.

\section{References}

1. American Academy of Pediatrics. Salmonella infections. Kimberlin DW, Brady MT, Jackson MA, Long SS (eds). Red Book: 2018 Report of the Committee on Infectious Diseases. $31^{\text {st }}$ ed. Itasca, IL: American Academy of Pediatrics, 2018:711-8. [CrossRef]

2. Lee WS, Puthucheary SD, Omar A. Salmonella meningitis and its complications in infants. J Paediatr Child Health 1999;35:379-82. [CrossRef]

3. Ghon J. Bericht über den XIV. Internationalen Kongress für Hygiene und Demographie (Berlin). Report on the XIVth international congress for hygiene and demographics (Berline). 1907;4:21-3. [CrossRef]

4. Molyneux EM, Mankhambo LA, Phiri A, Graham SM. The outcome of non-typhoidal salmonella meningitis in Malawian children, 1997-2006. Annals of Tropical Paediatrics 2009;29:13-22. [CrossRef]

5. Synnott MB, Morse DL, Hall SM. Neonatal meningitis in England and Wales : review of routine national data. Archives of Disease in Childhood 1994;71:F75-F80. [CrossRef]

6. Wu H, Huang W, Lee M, Yang AD, Chaou K, Hsieh L. Clinical features, acute complications, and outcome of Salmonella meningitis in children under one year of age in Taiwan. BMC Infect Dis 2011;11:30 [CrossRef]

7. Dower J, Lerner DP, Geva T, Wener K. The risk of immunosuppression: a case of salmonella meningitis. Case Reports in Infectious Diseases 2018;2018:1-3. [CrossRef]

8. Metan G, Alp E, Eşel D, Aygen B, Sümerkan B. Salmonella enteritidis: erişkin hastada nadir bir menenjit etkeni. Mikrobiyol Bul 2005;39:509-12. [CrossRef]

9. Brown M, Eykyn SJ. Non-typhoidal salmonella bacteraemia without gastroenteritis: a marker of underlying immunosuppression. Review of cases at St. Thomas' Hospital 1970-1999. J Infect 2000;41:256-9. [CrossRef]

10. Dougan G, John V, Palmer S, Mastroeni P. Immunity to salmonellosis. Immunol Rev 2011;240:196-210. [CrossRef]

11. Sirinavin S, Chiemchanya S, Vorachit M. Systemic nontyphoidal salmonella infection in normal infants in Thailand. Pediatr Infect Dis J 2001;20(6):581-7. [CrossRef]

12. Huang $L, K o S$, Lui C. Salmonella meningitis: clinical experience of thirdgeneration cephalosporins. Acta Pediatr 1997;86:1056-8. [CrossRef]

13. Tapia MD, Tennant SM, Bornstein K, Onwuchekwa U, Tamboura B, Maiga $A$, et al. Invasive nontyphoidal salmonella infections among children in Mali, 2002-2014: microbiological and epidemiologic features guide vaccine development. Clin Infect Dis 2015;61(Suppl 4):332-8. [CrossRef]

14. Wen $\mathrm{SCH}$, Best $E$, Nourse C. Non-typhoidal salmonella infections in children: review of literature and recommendations for management. $J$ Paediatr Child Health 2017;1-6. [CrossRef]

15. Price EH, Louvois J De, Workman MR. Antibiotics for salmonella meningitis in children. J Antimicrob Chemother 2000;46:653-5. 